\title{
The Reverend Russell H. Conwell, W. Wayne Babcock, and the "soup bone" cranioplasties of 1915
}

\author{
Adam L. Sandler, M.D., ${ }^{1,2}$ Arundhati Biswas, M.D., M.Ch., ${ }^{1,2}$ \\ and James Tait Goodrich, M.D., Ph.D. ${ }^{1,2}$ \\ ${ }^{1}$ Department of Neurological Surgery, Albert Einstein College of Medicine of Yeshiva University/Montefiore \\ Medical Center; and ${ }^{2}$ Division of Pediatric Neurological Surgery, Albert Einstein College of Medicine of \\ Yeshiva University/The Children's Hospital at Montefiore, Bronx, New York
}

\begin{abstract}
In 1915, faced with 2 patients with large skull defects, W. Wayne Babcock, an obstetrician-gynecologist-turnedgeneral surgeon, operating in a modest North Philadelphia hospital, did something extraordinary: he went to the hospital kitchen to look for a cranial graft. Based heavily on archival and other primary sources, the authors tell the remarkable tale of the "soup bone" cranioplasties of the Samaritan Hospital and place these operations within the context of the early modern American hospital.
\end{abstract}

(http://thejns.org/doi/abs/10.3171/2014.2.FOCUS13573)

KEY WORDS • history • cranioplasty • soup bone • implant

\begin{abstract}
"We shall not scorn what was done yesterday because we have something better today any more than our interest in the past will cause us to continue the practice of the past." 5
\end{abstract}

W. WAyne BABCock, TEXTBOOK OF SURGERY

In 1917, a short, yet remarkable paper was published in the Journal of the American Medical Association describing an unusually creative cranioplasty involving the use of "soup bones." The paper's author was W. Wayne Babcock, chief of surgery at North Philadelphia's Samaritan Hospital. Two patients received the soup bones and both experienced successful cosmetic and clinical outcomes. Here the authors explore the historical context behind this innovative choice of cranial graft and situate the surgery and the Samaritan Hospital within the context of early institutional American medicine.

\section{The Patients}

In 1903, somewhere near Bonn, Germany, an otherwise healthy 21-year-old laundryman apparently shot himself accidentally while cleaning a service revolver. A single bullet entered his right temporal bone, "about two inches in front of the upper lobe of the right ear," took a "forward and upward" trajectory, and lodged in his skull. ${ }^{4}$ The man was taken to a hospital in Bonn, where surgeons removed "part of the temporal and frontal bones down to and including the right supra-orbital ridge."4 After a 2-week convalescence, the surgeons reoperated and repaired the cranial defect by injecting paraffin under the skin flap. Although the patient recovered fully, the paraffin gradually softened and became "lumpy and irregular."

That same German laundryman would eventually make his way to Philadelphia, Pennsylvania, where, 9 years after his unfortunate accident with the revolver, he began to experience "epileptic convulsions." ${ }^{4}$ In the hopes of ameliorating these seizures, he had the paraffin removed in 1912. The symptoms, however, persisted. He presented to the Samaritan Hospital in April 1915 complaining of "convulsions" and "troublesome headaches."

On January 16, 1915, an unknown man of Irish extraction was brought unconscious to North Philadelphia's Samaritan Hospital by a group of fellow passengers after the man apparently had a seizure while riding on a nearby trolley car. ${ }^{4}$ Physical examination revealed a "large defect of the skull," and while the attending physician was palpating the said defect, the patient had a second seizure. ${ }^{4}$ Once he regained consciousness, the man stated his name and age (39 years) and told the medical team that he had worked as a cowboy some years previously and had been kicked in the back of the head-the injury having necessitated an emergent right (parietooccipital) craniectomy. Although he survived the initial trauma, the patient stated he could not return to his previous profession, as "horseback riding, pressure over the depressed area, or nervous excitement incited convulsions." While in the Samaritan, the patient suddenly stood up, and when he did so, "there was a large cup-shaped depression in the right upper occipito-parietal region." ${ }^{4}$ When the patient bent over, the brain actually "bulged through the opening."4

\section{The Surgeon}

William Wayne Babcock was born in East Worcester, New York on June 10, 1872. At the age of 21, in 1893, 
he received a medical degree from the College of Physicians and Surgeons in Baltimore. After spending a year as a resident physician in Salt Lake City, he matriculated at the University of Pennsylvania and received a second medical degree from that institution in 1895. In the ensuing 7 years before joining the Samaritan Hospital as its surgeon, Dr. Babcock would hold a diverse array of positions within the medical community of greater Philadelphia, including pathologist and surgeon at the Kensington Hospital for Women as well as demonstrator and lecturer in pathology and bacteriology at the Medico-Chirurgical College of Philadelphia (from which he would later receive training in gynecology and his third medical degree).$^{12} \mathrm{He}$ joined the Samaritan Hospital as the chair of gynecology (and then surgery) in 1903 (Fig. 1). ${ }^{27}$

\section{North Philadelphia}

In the late 1800s, North Philadelphia was a robust industrial center, home to a variety of factories and foundries, as well as the Baldwin Locomotive Works-the country's leading manufacturer of steam engines at the time. ${ }^{16,32}$ The large concentration of factories in the area meant that North Philadelphia was unfortunately awash in industrial accidents. ${ }^{16}$ With the nearest medical facilities located in Center City and Germantown, there arose a need for a well-equipped hospital to treat those "burned and bruised and maimed" workers of North Philadelphia

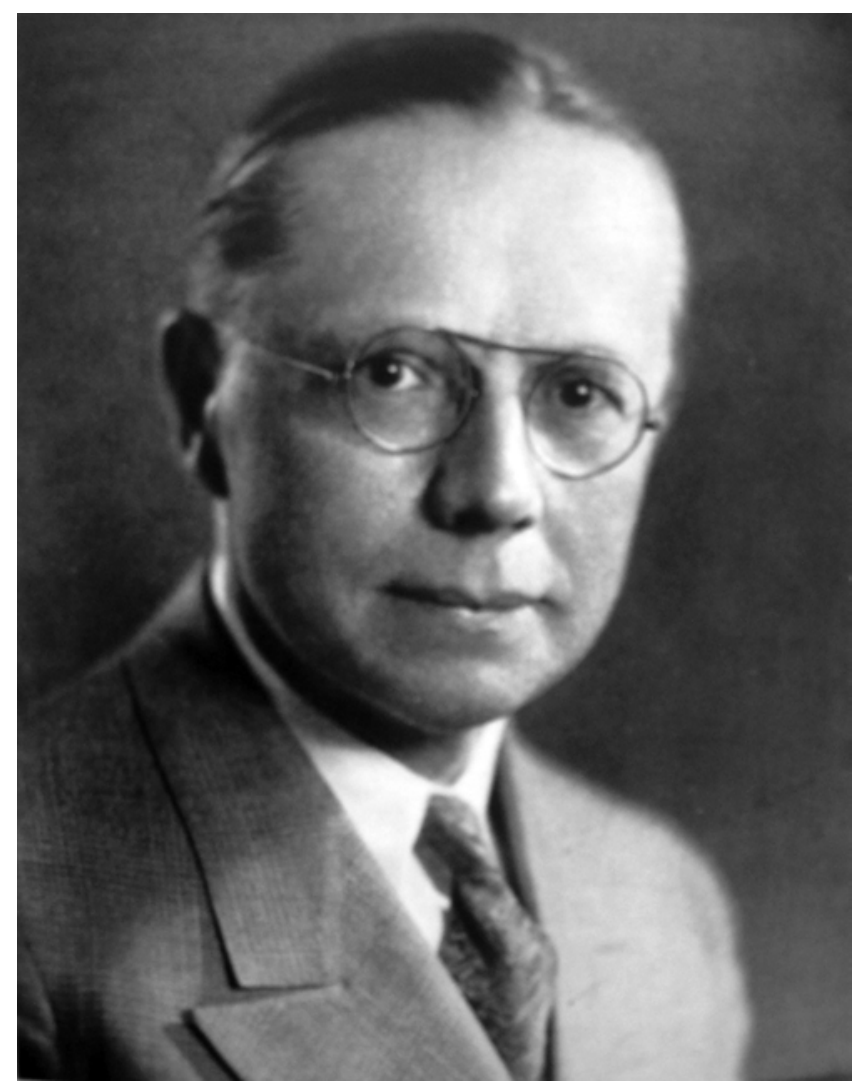

FIG. 1. An undated photograph of a young Dr. William Wayne Babcock. The Babcock File. Courtesy Special Collections Research Center, Temple University Libraries, Philadelphia, PA. and to provide at least a semblance of medical care to their growing families. ${ }^{16}$

In 1890, a charter for the "North Philadelphia Hospital" was granted to a group of 5 physicians living in the neighborhood between Broad and Ontario Streets. The small hospital consisted of one floor in a brick building on North Broad Street. Strangely, the North Philadelphia Hospital closed only 1 year after its opening, apparently due to lack of funds. ${ }^{14}$ Concerned for the well-being of her neighbors, a woman who resided in North Philadelphia wrote a letter to her church pastor, petitioning him to intervene and reorganize the hospital. ${ }^{15}$ That letter would set in motion the establishment of the Samaritan Hospital, and ultimately led to the establishment of the Temple University Hospital and its School of Medicine.

\section{The Pastor and His Hospital}

The woman who wrote the letter petitioning to save the North Philadelphia Hospital was a member of the Grace Baptist Church. The man to whom the letter was addressed was the Rev. Russell H. Conwell-a dynamic orator, talented fundraiser, and widely popular Baptist minister who had assumed leadership of the church 8 years earlier in 1882 (Fig. 2).

Conwell's biography, particularly his early experiences and life trajectory prior to his position within the church, is fascinating - and certainly somewhat atypical for a 19th century Baptist minister. Born and raised in rural Massachusetts to a family of poor Methodist farmers, at age 14 Conwell attended the Wilbraham Wesleyan Academy-the only Methodist preparatory school in New England at the time-where he developed a keen interest in public speaking. ${ }^{9}$ His talents at debate were so impressive that by his second year in the school he was actually appointed as an instructor in "elocution and reading." $\mathrm{He}$ was accepted to, and enrolled in, Yale University in 1859, hoping to study law. While attending the university, the future Baptist minister embraced atheism. The outbreak of the Civil War cut Conwell's Yale career short as he enlisted in the Union army in 1861.9,20

After enlisting he immediately began recruiting volunteers to the Union cause from the towns around his childhood farm in western Massachusetts. Conwell's enthusiasm, public speaking skills, and ability to attract and motivate followers caught the attention of Massachusetts Governor John Andrew who commissioned the 19-year-old Conwell as a captain in the 46th Massachusetts Volunteer Militia. ${ }^{9}{ }^{, 10}$ Conwell's regiment saw action while stationed near Newport, North Carolina, and he appears to have been severely wounded in 1864 at the Battle of Kenesaw Mountain, Georgia ${ }^{34}$ Left for dead on the battlefield, with the moans of dying comrades and combatants around him, Conwell experienced a spiritual reawakening of sorts. ${ }^{10}$ After being rescued and taken to a military hospital, he promised the army chaplain that he would "dedicate his life to the cause of Christ and the good of others."

Conwell would fulfill the promise of his battlefield conversion gradually. When Lee surrendered to Grant at Appomattox in 1865, Conwell was 23 years old. For the 


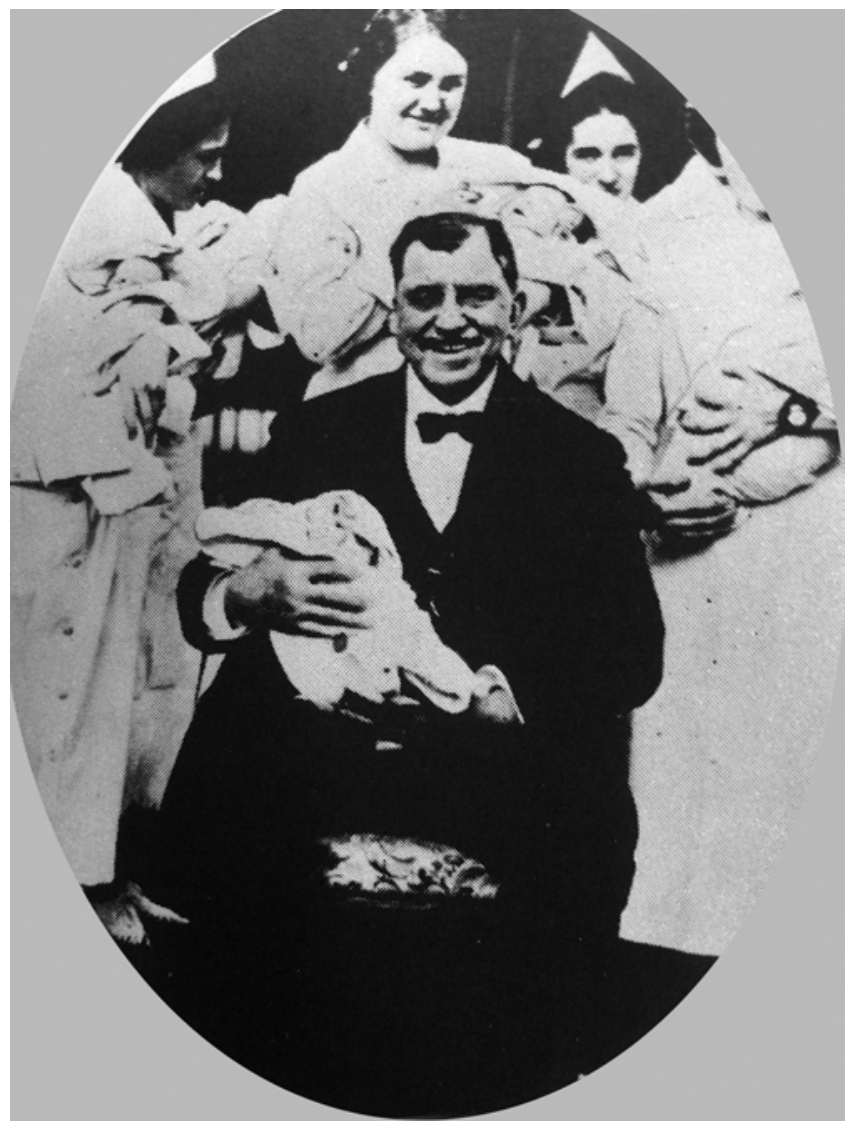

FIG. 2. Photograph of the Rev. Dr. Russell H. Conwell holding a baby in the Samaritan Hospital published in The Temple Review, March 30, 1917. Courtesy Special Collections Research Center, Temple University Libraries, Philadelphia, PA.

next 17 years of his life, until he became pastor of the Grace Baptist Church, Conwell would marry, become a widower, remarry, attend law school in Albany, practice law successfully in Minnesota and Massachusetts, write as a journalist for the St. Paul Press, Minneapolis Tribune, Boston Traveler, and New York Tribune, manage and invest in real estate, serve as an immigration agent for Germany, travel alone in Europe for a year, lecture throughout the United States on a variety of subjects, and publish biographies of Ulysses S. Grant and Rutherford B. Hayes..$^{9,10}$

During these years the seeds of Conwell's piety and potential as a religious leader continued to germinate. While in Minnesota, he made a habit of organizing a daily prayer meeting in his law office. In Massachusetts, Conwell took out an ad in the local paper pledging to provide "legal advice or assistance free of charge" to "any deserving poor person." 34 He also founded a popular Bible class affiliated with the local Baptist church. Scripture and sermons were not enough-Conwell's study group actively distributed charity to Boston's poor. In 1879, Conwell finally fully fulfilled his Civil War vow-he made a clean break from law and real estate, studying at the Newton Theological Seminary, becoming an ordained minister, and subsequently leading a small Baptist church in Lexington, Massachusetts. ${ }^{9}$ It was within the church that the rhetorical skills Conwell had cultivated as a schoolboy, debate instructor, public lecturer, and lawyer would find their greatest expression. ${ }^{9}$ It was these oratory talents as well as his success as a fund-raiser and organizer (he had saved his Lexington church from financial ruin) that led the deacons of the fledgling Grace Baptist Church on North Philadelphia's Broad Street to offer the pulpit to this upstart pastor in 1882..$^{9,10}$

\section{Genesis of the Samaritan}

The deacons' decision proved wise. In less than a year since Conwell assumed its helm, the church's membership swelled. Indeed, over 1200 people would squeeze into the holy edifice for a given Sunday service. ${ }^{10}$ Buoyed by booming membership, the small church purchased land within several blocks of its location and construction began in earnest on a new Church-dubbed affectionately as "the Temple" by the locals - in March of 1891. This new Temple could safely seat 3135 people, making it the largest Protestant church in America at the time..$^{20}$

Thus, in 1890, when the North Philadelphia woman appealed to her pastor to intervene following the demise of the North Philadelphia Hospital, she was writing to a man who could galvanize people to support any cause: She was, in essence, asking Conwell to build a hospital.

Conwell would not disappoint his congregant. He dispatched the church's financial officer to the North Philadelphia Hospital, and "arrangements were made to take over the usable furniture and equipment."15 The building itself was deemed inadequate so Conwell asked one of his congregants who belonged "to a family well-known for their numerous benefactions among Baptist enterprises" to donate $\$ 1000$ for a down payment on a 2 -level house at the corner of Broad and Ontario streets. ${ }^{14,15}$ Other church members volunteered to "clean and scrub the floors," and a "heater man" offered to repair the building's furnace..$^{15}$ Additional supplies and furniture were "begged, borrowed, and paid for" by still more congregants. ${ }^{15}$ For an ambulance, ironically, the community undertaker donated one of his "vehicles," a local restaurant proprietor donated "a magnificent set of harnesses," and a certain Peter A.B. Widener, magnate of the Traction Company (which specialized in the manufacturer of trolley cars), donated 2 horses, named by the hospital staff as "Pete" and "Widener," who dutifully pulled accident victims to safety in the Samaritan Hospital's horse-drawn ambulance for over 10 years (Fig. 3$).{ }^{15}$

The hospital remained a source of great pride to Conwell and his ever-growing congregation. Influenced by the importance of the printed word through his prior career as a newsman, Conwell and his "Temple" community sponsored its own weekly newsletter, The Temple Magazine (later, The Temple Review) which, in addition to publishing Conwell's weekly sermon, included regular updates on the hospital. It was undoubtedly important for Conwell keep his many church members and supporters abreast of the hospital's happenings. Indeed, while the Samaritan received a charter and some funding from the state by 1893 , it still remained almost entirely dependent on the generosity and volunteerism of Conwell's con- 


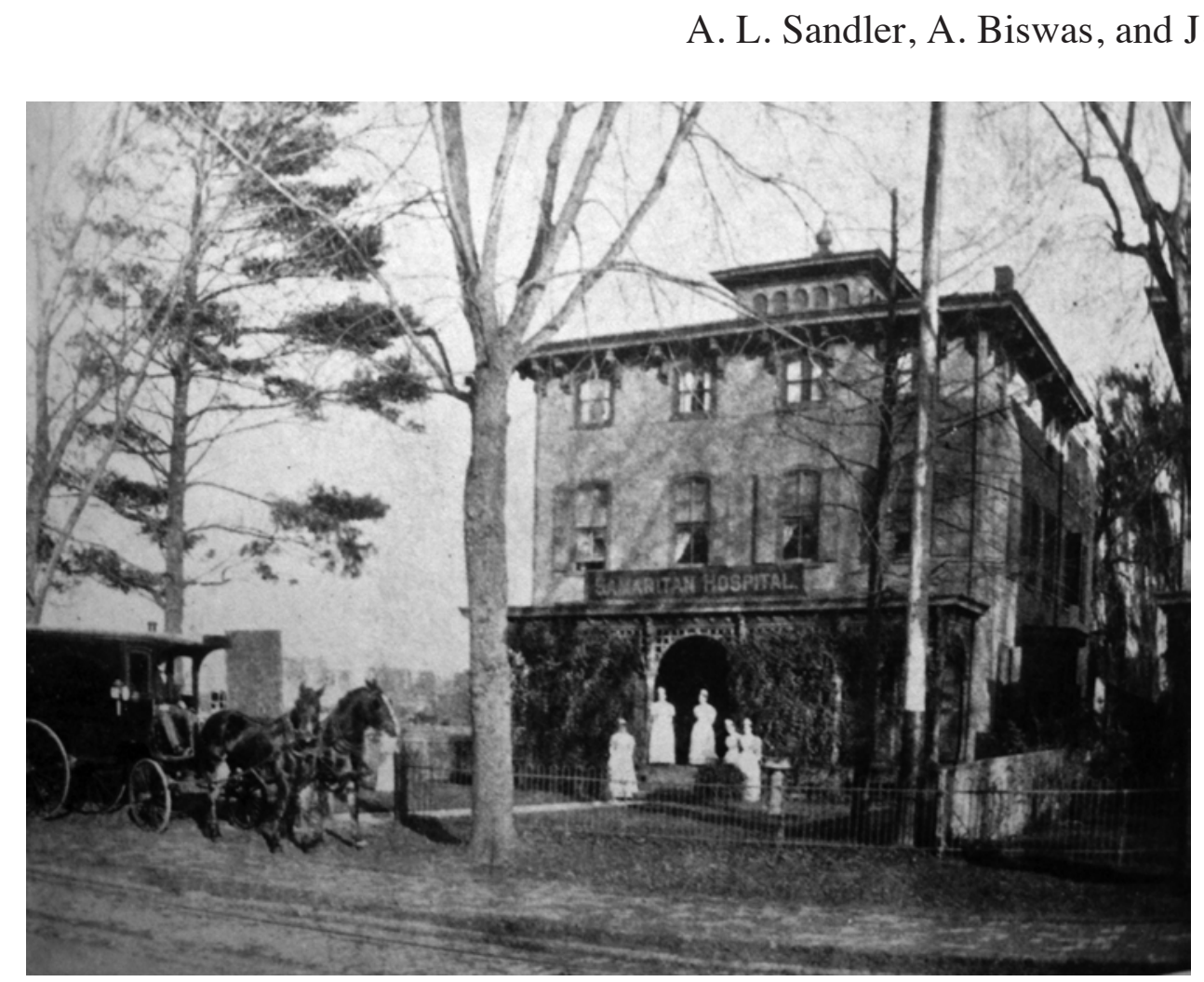

FIG. 3. Photograph of the Samaritan Hospital, showing the nursing staff waiting to receive patients from the horse-drawn ambulance. Samaritan Hospital 1892. The Samaritan Hospital File. Courtesy Special Collections Research Center, Temple University Libraries, Philadelphia, PA.

gregants. ${ }^{14}$ Even the nonmedically inclined subscribers to The Temple Magazine must have been fascinated by the dramatic retelling of the "unusually large number of acute accidents" such as "a man injured by a wagon running over him," 4 factory workers seriously injured in an explosion, and another patient admitted for "heat exhaustion." 14,15 Ever the effective fund-raiser, Conwell's magazine always followed the reporting of enticing hospital tidbits like "two more operations were performed last week, and both cases are doing well," with a sobering plea to his congregants to "come, join the army of earnest workers for the uplifting of the Good Samaritan Cause!"15,37 Conwell also made sure that the particular generosity of each individual church member did not go unnoticed. It seemed almost every donation of good and service -no matter how trifling-was published in his Magazine:

"Among the donations recently received was a lot of linen...given through Mrs. Wm. Worrell." ${ }^{36}$

"Mr. Chas L. Peterson very kindly did some carpentry for us as a donation to the Hospital." ${ }^{36}$

"A contribution of five dollars has been received... from Mrs. John Baird."36

Those many church members who donated their time, money, and talents surely felt a sense of satisfaction over "the grand humanitarian work," and even Dr. Babcock donated directly to the hospital. In a listing of recent donations to the Samaritan appearing in The Temple Review, interposed between contributions of " 1 dozen infants' socks" and "1 dozen bottles olive oil," reads the following: "Dr. W. Wayne Babcock, 2033 Walnut St., 4 7-inch dressing forceps, 65 1/4-inch straight scissors, 4 probes, 4 grooved directors" (Fig. 4).

\section{A Center for Trauma Surgery}

At its inception, the chief aim of this 2-level houseturned-hospital was to serve as a surgical center specializing in the treatment of traumatic injuries. Patients suffering from chronic and contagious diseases were not admitted. Thus the first floor of the 20-bed hospital housed the men's surgical ward as well as the outpatient surgical "dispensary (Fig. 5)."' The first floor also held the "parlor, dining room, and kitchen." 2 Thus, originally the surgical ward and hospital kitchen were in close proximity.

The first operation in the Samaritan was performed on February 15, 1892, likely by the hospital's first chief of surgery, the South-African born, Yale-educated, Edmund Wales Holmes (1852-1905). ${ }^{14,24}$ In addition to his role at the Samaritan, Holmes served simultaneously as demonstrator of anatomy at the University of Pennsylvania (his 1897 book, Outline of Anatomy, was a popular teaching text for medical students of the era) and consulting surgeon to the Pennsylvania State Asylum for the Insane. ${ }^{24}$ What the Samaritan lacked in appearances-"the whole place more resembles a private house" wrote a reporter for The Philadelphia Times - it more than made up for in its high quality care and surgical volume (Fig. 6). ${ }^{14}$ "The surgical work of the institution is becoming famous;"35 "many delicate and diverse operations are performed in the Surgical Department," boasted Conwell's weekly newsletter. ${ }^{29}$ At least 


\section{SAMARITAN HOSPITAL}

The following donations are gratefully acknowledged:

Mrs. John R. Young, 4536 N. Broad St., 10 pillow cases ; Mrs. Edward 'Vanatta, 1828 N. Willington St., 1 dozen sheets; Mrs. Clara Bloch, 1633 N. 32d St., 1 wheel chair; Miss Marion Hartman, 2 mirrors; Mr. E. K. Worthline, 1818 Cayuga St., flowers; Mrs. Calhoun, 3229 Hurley St., magazines; Mr. Martin J. Hesch, 3346 Germantown Ave., 33 quarts ice cream; Mrs. Charles Thompson, Mrs. Mae Adamson, 4811 Germantown Ave., flowers; Mrs. Arthur D. Kurtz, 2520 N. 22d St., 1 dozen glasses of jelly; Mr. and Mrs. George F. Ward, Miss Ella R. Otto, Mrs. E. O. Sanborn, 231 Apsley St., through Dr. H. Brooker Mills, cards for the children's ward; Board of Lady Visitors, through Mrs. Frank L. Fowler, 2321 N. 13th St., 2 dozen outing flannel slips, 1 dozen outing flannel petticoats, 1 dozen infants' socks; Dr. W. Wayne Babcock, 2033 . Walnut St., 47 -inch dressing forceps, $651 / 4$-inch straight scissors, 4 probes, 4 grooved directors; H. J. Heinz Co., 12th and Sedgley Ave., 1 dozen bottles olive oil.

Fig. 4. List of donations to the Samaritan Hospital published in The Temple Review, March 1917. Courtesy Special Collections Research Center, Temple University Libraries, Philadelphia, PA. as early as 1892 , surgeons at the Samaritan were treating cranial trauma, as shown by the following report of a skull fracture from The Temple Magazine:

Three operations were performed since the last issue of the Magazine. One of them was trepanning the skull for a compound depressed fracture in a child aged seven years. This operation is one of extreme delicacy and requires the most skilled and careful nursing after the performance. We are happy to say the child is doing well and will, in all probability, make a good recovery. ${ }^{37}$

The real watershed in the surgical history of the Samaritan would begin in 1903, when Conwell recruited the 31-year-old William Wayne Babcock to serve as the hospital's obstetrician-gynecologist. While Babcock accepted the post, he apparently had his eye on the position of chief surgeon, a title he would receive later that year and hold continuously for the next 40 years. ${ }^{12,27}$ In Babcock, Conwell undoubtedly found a kindred spirit. Babcock was a surgical innovator in the truest sense, and the steady supply of surgical patients at the Samaritan afforded him the opportunity to advance his field. In 1907, Babcock published a series of 4 cases in which he performed a type of neurolysis to relieve "certain painful or paralytic conditions of nerve trunks." ${ }^{\circ} \mathrm{He}$ (correctly) concluded: "that the surgical disassociation of nerve fibers may be carried out without producing gross evidence of reduction in the conducting power of the nerve." Eight years after this paper, in 1915, the obstetrician-turned-general-surgeon would again focus his attention on another neurosurgical problem-namely, the lack of effective implant material for cranioplasty.

\section{Feeding the Sick at the Samaritan: Mutton Bone Soup}

Remarkably, the original 1896 pamphlet detailing

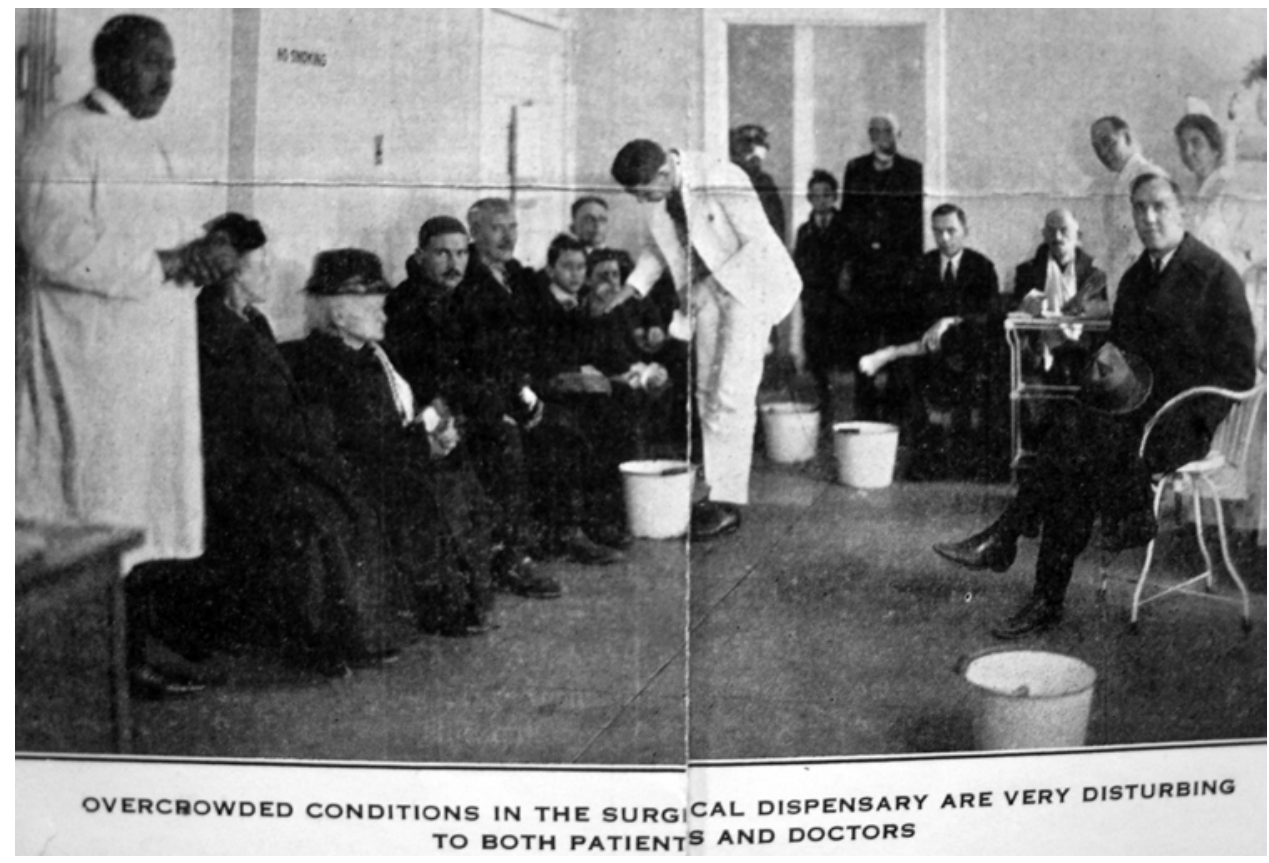

FIG. 5. Photograph of the surgical "outpatient" dispensary Samaritan Hospital 1923 published in The Temple Review, February 20, 1923. Courtesy Special Collections Research Center, Temple University Libraries, Philadelphia, PA. 


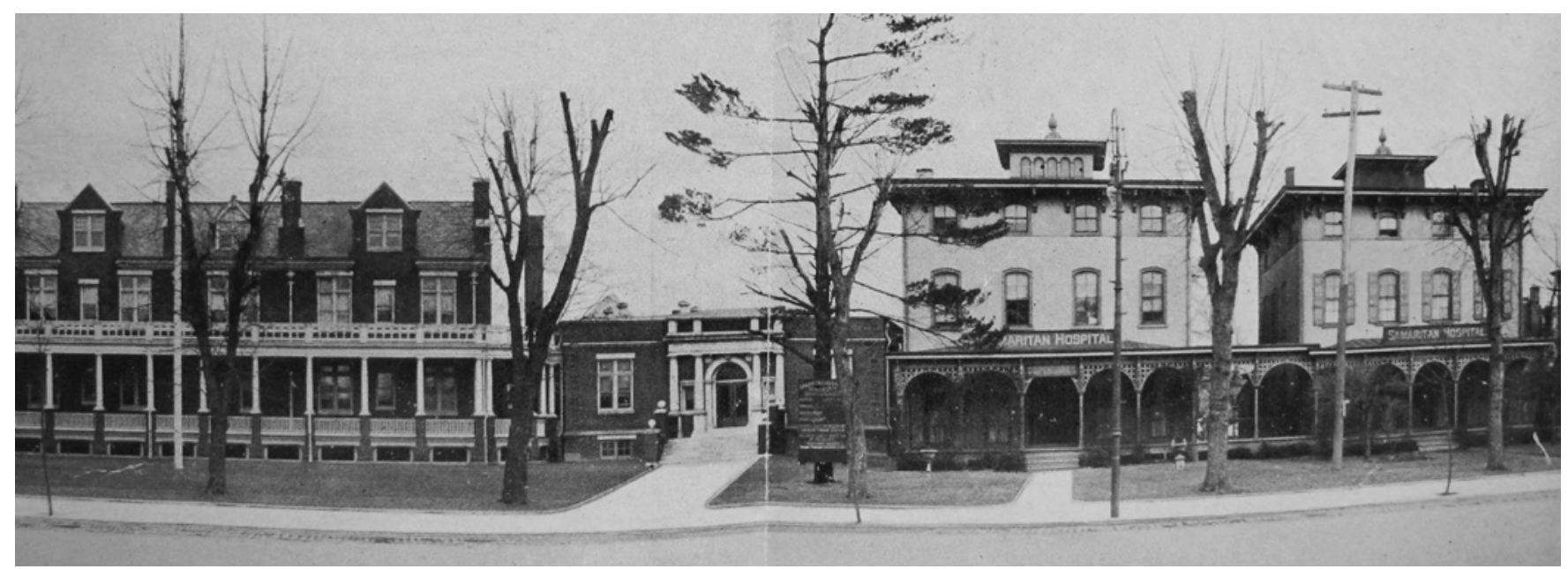

FIG. 6. A 1909 photograph of the expanding Samaritan Hospital. Even as the hospital grew it still retained its look of a converted home. Courtesy Special Collections Research Center, Temple University Libraries, Philadelphia, PA.

the "Rules and Regulations for the Government of the Samaritan Hospital of Philadelphia" survives intact in the archives of the Paley Library of Temple University. ${ }^{28}$ This rule book offers a fascinating window into the inner workings of an early American hospital. It may also shed light on the background behind Babcock's choice of "mutton bone from the hospital's soup kettle" for his cranial implant. ${ }^{4}$ As Rule 14 states, at the Samaritan, the patient's nutrition was not solely the responsibility of the hospital matron and kitchen staff.

Rule 14. The Surgeon and Physician on duty shall constitute an Executive Committee, whose duty it shall be to inspect, at least once a week, the Hospital buildings, and maintain a general supervision over the cleanliness of the wards, water closets, laundry...They shall also enquire into the quality of the food, drugs, and such other matters as may be important to the welfare of the Hospital..$^{28}$

Thus it would seem that Babcock was himself expected to have at least some working knowledge of the food that was being served to his patients. The specific food served to the patients at the Samaritan was donated by volunteers, refrigerated, and cooked in "machinery like that used in mammoth hotel kitchens," and regulated by the matron., ${ }^{1,28}$

Rule 2. No liquors, provisions, nor medicine of any kind shall be furnished to the patients by their friends; and no patient shall be permitted to have any diet or prescription prepared in the house, other than that ordered by the Medical Officers. ${ }^{28}$

Of the foods prepared for patients at the Samaritan, mutton bone soup was apparently common enough for Babcock to have drawn a bone from the kettle for his cranioplasties on more than one occasion. Generally, "mutton" refers to the flesh of a sheep over the age of 1 year, in contrast to the younger, milder, and generally less fatty, yearling lamb. Even in 1915, mutton was decidedly less popular than lamb in the United States, but, judging by the advertisements of various butchers and victualers in The Temple Magazine (Fig. 7), mutton was readily available in North Philadelphia and was reputed due to its relatively high digestibility. ${ }^{19}$ A pamphlet titled Mutton and its Value in the Diet, produced by the US Department of Agriculture in 1913, notes that "mutton and lamb are commonly believed to digest readily, without causing disturbance and the results of scientific investigations seem to bear out this belief. To this may be ascribed the common use of mutton and lamb in invalid dietetics." 19 The 1887 American book Cookery for Invalids gives a recipe for mutton broth and recommends adding "a very small piece of onion...to destroy the peculiar mutton flavor which is so objectionable to many patients." 23

\section{Cranioplasty circa 1915: The State-of-the-Art}

That Babcock would turn to the hospital kitchen for his cranioplasties seems unquestionably odd to the modern reader. In truth, the use of soup bones meshes well within the overall hodgepodge of autograft, xenograft, metals, and synthetic materials that were being used by resourceful surgeons throughout the world at the time. 3,30,33 "Much ingenuity has been expended," wrote Babcock, "in the correction of these various defects." Babcock knew that for small defects, autograft from the outer table was ideal, "but was not so practicable for larger ones."4 Though he acknowledged that others had used metals, such as silver and gold, and synthetic materials, such as celluloid, hard rubber, cork, and paraffin, Babcock felt that "many of these substances... [were] undesirable...The alien substance may cause such a profuse serous secretion in the wound, or tissue irritation, as to necessitate removal."'

Autograft, it seemed to Babcock, avoided the inflammatory complications of metals and synthetic materials and had "the advantage of being well tolerated." 4 The main drawback of harvesting autogenous bone, however, is that it "required an additional operation with its added risk." " Nonetheless, Babcock readily acknowledged that good results had been obtained with scapular and/or iliac bone by Mauclaire, with sternum by Müller, and with rib by Kahle. He seems to have favored the soup bone over these autografts, then, because of its "convenient accessibility." $18,21,22$

Animal bone, it should be noted, also had a prominent 


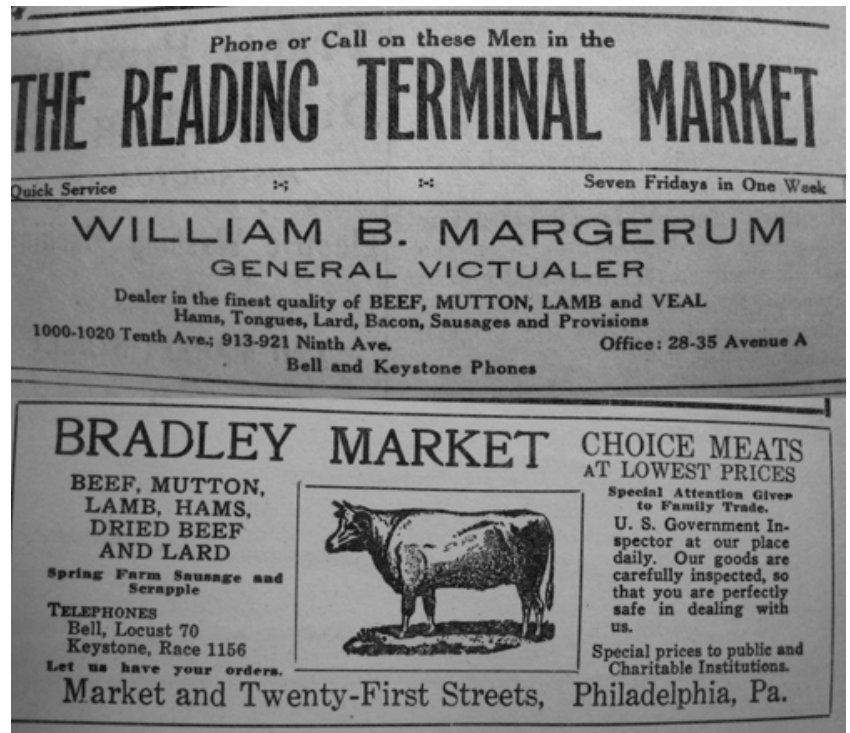

Fig. 7. Advertisements for sellers of mutton in The Temple Review, January 5, 1917. Judging by these advertisements, Babcock would have had a ready supply for his cranial grafts. Courtesy Special Collections Research Center, Temple University Libraries, Philadelphia, PA.

role in cranioplasty in the late 19th and early 20 th centuries. Surgeons had made use of ivory for years to correct cranial defects. ${ }^{30,31}$ Bone from ape, ox, rabbit, goose, dog, buffalo, sheep, and eagle had also been used prior to (and following) Babcock's mutton. ${ }^{3,30}$ Though the neck bone was more commonly used in mutton soup, it appears that Babcock's soup bone was scapula. ${ }^{4,7,8,26}$ Animal scapula had a particularly promising history as a graft -17 years before Babcock, in 1898, Grekoff calcined the scapula of a calf and implanted it successfully in 2 children with good results. ${ }^{17}$

\section{The "Soup-Bone" Cranioplasties}

Babcock published the results of his creative culinary cranioplasty after a 2-year follow-up period in the Journal of the American Medical Assocation in 1917. In this short report, Babcock gives a stepwise account of his technique. It seems that the surgeon literally removed the mutton bone from the boiling soup kettle (rather than as a frozen specimen from the refrigerator), as this "has the advantage of having less animal matter than fresh bone." Babcock warned not to over-boil the bone, however, lest it be "rendered too brittle."4 Once he had selected a scapula from the pot, he rinsed it off (perhaps to remove the residue of onion, carrot, and turnip), boiled it again for 1 hour, let it sit overnight in a 1:20 solution of phenol, and then boiled it again the following day for 30 minutes. The suggestion of boiling the bone before attaching it to the skull was relatively new, having appeared in a report by Westermann only 1 year earlier. ${ }^{38}$ In addition to its obvious benefits in cleaning the graft, Babcock noted that after boiling "the bone is somewhat softened and can be readily cut into the desired shape."'4 Next the scapula was prepared by removing its spine and rough edges, contouring it to the required shape, and perforating it "by many drill holes placed about one-half inch apart" (Fig. 8). ${ }^{4}$ Babcock next raised a scalp flap, stripped back the periosteum, and fastened the "soup bone" to the skull with chromicized catgut."' So as to prevent the development of an extraaxial fluid collection he emphasized the need for "absolute hemostasis" but did not advocate for placement of a drain. ${ }^{4}$

After detailing his technique Babcock presents the 2 patients who underwent this procedure. The German laundryman experienced "a marked reduction in the volume of convulsions... and had been practically free from headaches."4 To emphasize that the soup bone graft had taken successfully, Babcock further revealed that in September 1916, the unfortunate laundryman was "struck by a violent blow over the implant by a door, without harm."4 After 2 years, "the contour of the frontal region is well restored and shows no signs of absorption" (Fig. 9). ${ }^{4}$

Like the German laundryman, the Irish cowboy also had a good outcome. Babcock operated on this more posterior cranial defect under local anesthesia. He raised a skin flap and separated the dura and pericranium from the margins of the defect. This patient experienced a "transient hyperpyrexia" postoperatively which Babcock attributed to "alien proteins in the dead bone."' Postoperative fevers aside, the patient made a full recovery "being able to work and free from symptoms."

\section{Soup Bones for the Face?}

Satisfied with the effects of mutton in the skull, Babcock implanted it for syphilitic saddle nose in 3 patients by making an incision through "a wrinkle line in the forehead" and sliding the graft down under the skin of the nose abutting the nasal bones. ${ }^{4}$ The results of this procedure were less encouraging: in one patient the implant "caused considerable tension of the overlying skin, and there was some inflammatory reaction" that subsequently subsided. ${ }^{4}$ In another patient, "late suppuration occurred and the alien bone was removed."

\section{Conclusions}

Before Babcock, much of the pioneering work on cranioplasty occurred overseas. One can only wonder to what extent the humble origin of the Samaritan Hospital, the "can-do" attitude of the Temple community that built and supported it, and the pioneering spirit of its unconventional founder all played in laying the foundations for a surgical career characterized by creativity and innovation. ${ }^{12,13}$ Indeed, Babcock's many contributions to the fields of surgery and anesthesia would essentially eclipse this little-known story of soup bones. He stayed on at the Samaritan-which later became Temple University Hospital-for his entire career, serving as its chair of surgery for 40 years. In 1954, the American Medical Association awarded Babcock its 17th Distinguished Service Medal-among the highest honors an American physician can achieve-" "for outstanding contributions to medicine and humanity."13

Contribution to medicine and humanity also encapsulates the remarkable story of the creation of the Samar- 


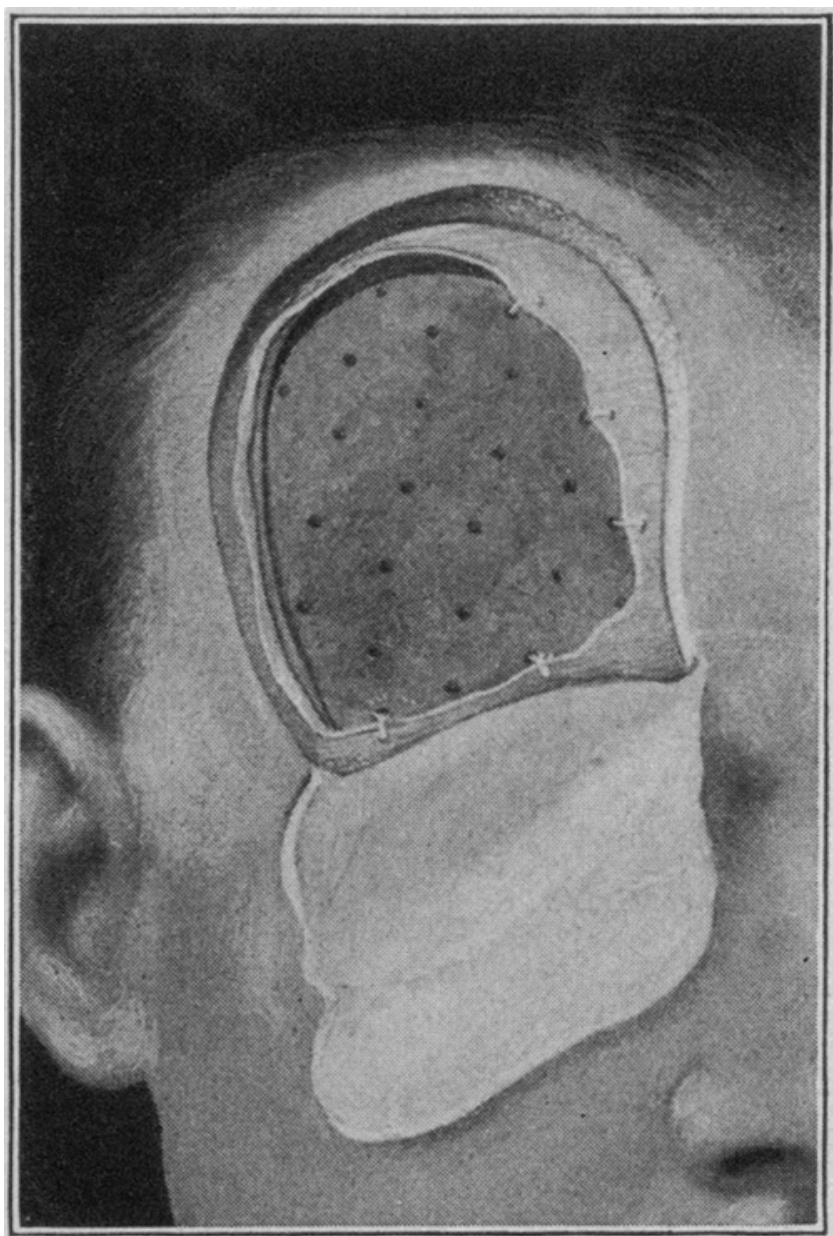

FIG. 8. An illustration of a frontotemporal "soup-bone cranioplasty." Journal of the American Medical Association 69:352-355, 1917.

itan Hospital, which, like that of many early American hospitals, is chiefly a story of American collectivisma community bound together by a common faith and spurred into action by the precepts of that faith to improve the lot of all men and women regardless of creed, country of origin, and (perhaps most significantly) ability to pay. ${ }^{1}$ Economic and demographic changes would alter the North Philadelphia landscape; gunshots and stabbings have replaced factory explosions and trolley car accidents; yet the Samaritan (now Temple) still serves its mission as an accomplished Level 1 trauma center.

And what of the man who brought the young and yet-unproven Babcock to the Samaritan? Russell Conwell died in 1925, eight years after Babcock's paper was published in the Journal of the American Medical Association. It was said that when he died, "the whole city of Philadelphia mourned the loss."'14 In 1914, he was awarded a golden "Key to the State" by then Pennsylvania Attorney General John C. Bell. ${ }^{25}$ Conwell was also the first recipient of the Bok award, awarded annually to a Philadelphian who "acted and served in the best interests of the community" (http://www.philadelphiaaward. org/public_html/about.aspx). Although he led a large and influential church and founded the Samaritan Hospital and Temple University, Conwell might best be remem-

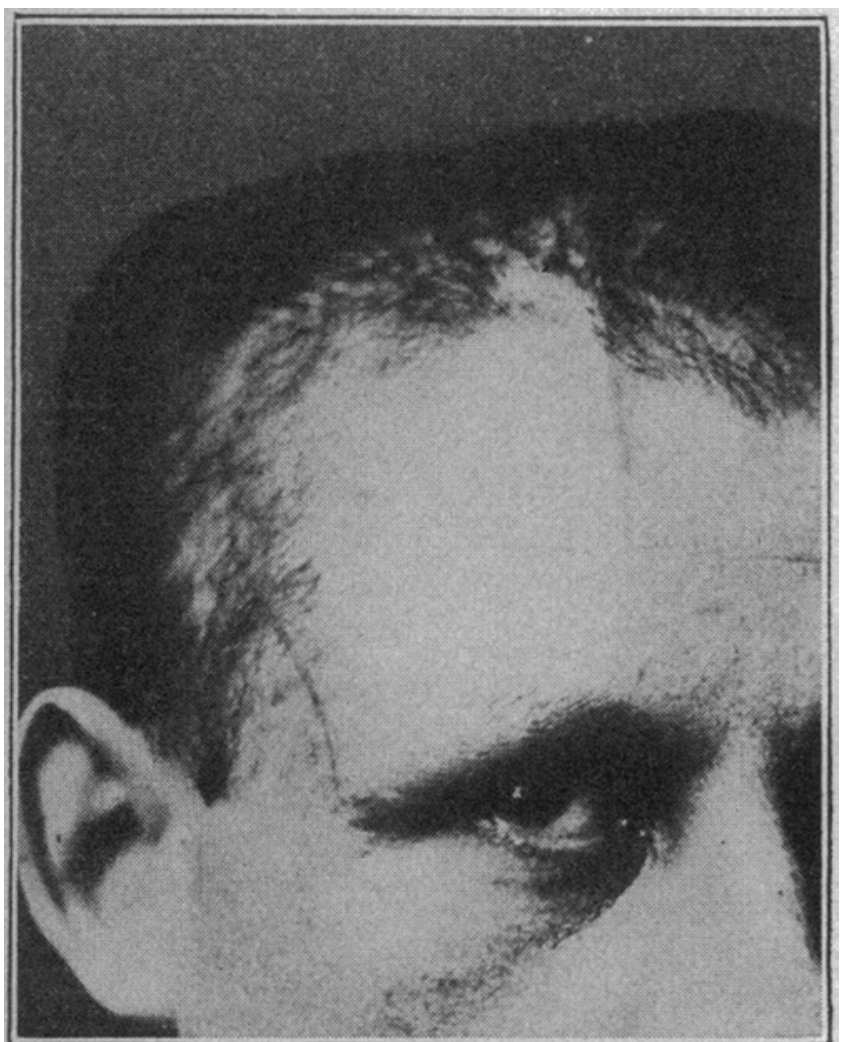

FIG. 9. Postoperative photograph. Note that the graft edges are clearly visible beneath the scalp. Journal of the American Medical Association 69:352-355, 1917.

bered for a popular sermon entitled "Acres of Diamonds," which he would preach a staggering 5000 times throughout the country. The speech, which he first delivered in 1890 , is based loosely on an old Middle Eastern tale of a farmer who spends his life traveling the earth searching for diamonds. After years of searching unsuccessfully the man commits suicide by jumping into a river. Soon after his death, the farmer who purchases his property finds a diamond mine on the very earth the dead man had abandoned years earlier. Conwell's message to ordinary Americans was clear: "life is not a treasure hunt. You can't look [outside yourself] for success...the treasure is within you."11 He inspired the audience further:

"Let every man or woman here, if you never hear me again, remember this, that if you wish to be great at all, you must begin where you are and what you are, in Philadelphia, now."11

And they heeded his call.

\section{Acknowledgment}

The primary author (A.L.S.) thanks Ruthie Rosenstock for her editorial and technological assistance.

\section{Disclosure}

The authors report no conflict of interest concerning the materials or methods used in this study or the findings specified in this paper.

Author contributions to the study and manuscript preparation include the following. Conception and design: Sandler. Drafting the article: Sandler, Biswas. Critically revising the article: Biswas, Goodrich. 


\section{References}

1. A stroll around Samaritan Hospital. Temple Review. September 8, 1905

2. A visit to the Samaritan Hospital. Temple Magazine IV:9-11, 1896

3. Albright AL, Pollack IF, Adelson PD (eds): Principles and Practice of Pediatric Neurosurgery, ed 2. New York: Thieme, 2008

4. Babcock WW: "Soup Bone" implant for the correction of defects of the skull and face. JAMA 69:352-355, 1917

5. Babcock WW: Textbook of Surgery, ed 2. Philadelphia: WB Saunders, 1935

6. Babcock WW: V. Nerve disassociation; a new method for the surgical relief of certain painful or paralytic affections of nerve trunks. Ann Surg 46:686-693, 1907

7. Beeton IM: The Book of Household Management. London: Ward Lock and Tyler, 1888

8. Beeton IM: The Management of Children in Health and Sickness. London: Ward Lock and Tyler, 1873

9. Bjork DW: Russell H. Conwell and the Crisis of American Individualism [dissertation]. Norman, OK: University of Oklahoma, 1973

10. Burr AR: Russell H. Conwell and His Work: One Man's Interpretation of Life. Philadelphia: John C Winston, 1917

11. Conwell RH, Shackleton R: Acres of Diamonds. New York: Harper \& Brothers, 1915

12. Corman ML: Classic articles in colonic and rectal surgery. William Wayne Babcock, 1872-1963. The operative treatment of carcinoma of the rectosigmoid with methods for the elimination of colostomy. Dis Colon Rectum 32:442-447, 1989

13. Dr. William W. Babcock awarded distinguished service medal. JAMA 155:912, 1954

14. Eberwein CA: The Samaritan Hospital. Germantowne Crier 18:109-113, 1966

15. Elliott EO: Tent to Temple: A History of the Grace Baptist Church, Philadelphia, Pa., 1870 to 1895. Jenkintown, PA: Times Chronicle Co, 1946

16. Garretson hospital fills unique need in industrial centre: accident cases treated by hundreds. Temple Review. 1917

17. Hare HA: Progressive Medicine. Philadelphia: Lea \& Febiger, 1900, Vol 1

18. Kahle RR: Use of autogenous rib graft in reconstructive skull surgery. JAMA 65:222-223, 1915

19. Langworthy CF, Hunt CL: Mutton and its Value in the Diet. Washington, DC: US Department of Agriculture, 1913

20. Lee RE: Incidents in the life of Russell H. Conwell. Temp LQ 17:209, 1942

21. Mauclaire P: Autogreffe crânienne empruntée à la tubérosité iliaque, et homogreffe séreuse interméningo-encéphalique. Bull Mem Soc Chir Paris 40:113-115, 1914

22. Mueller P: Deckung von Schädeldefekten aus dem Sternum. Zentralbl Chir 23:409-410, 1915

23. Murrey TJ: Cookery for Invalids. New York: White Stokes \& Allen, 1887

24. Obituary Record of Graduates of Yale University: Deceased From June, 1900 to June, 1910. New Haven, CT: Tuttle, Morehouse, \& Taylor Co, 1910

25. Parade takes minister to his 5000th lecture. Philadelphia Record. May 22, 1914. (http://www.phillyppa.com/52214.html) [Accessed February 18, 2014]

26. Potts CG: Farm Slaughtering and Use of Lamb and Mutton. Washington, DC: US Department of Agriculture, 1920

27. Rodgers FB: The Samaritan and how it grew. Temple University Alumni Review 18:2-6, 1966

28. Rules and Regulations for the Government of the Samaritan Hospital of Philadelphia. Samaritan Hospital File Archives, Paley Library, 1896

29. Samaritan Hospital building campaign: interesting hospital facts. Temple Review. 1923

30. Sanan A, Haines SJ: Repairing holes in the head: a history of cranioplasty. Neurosurgery 40:588-603, 1997

31. Santoni-Rugiu P, Sykes PJ: Skull reconstruction, in: A History of Plastic Surgery. New York: Springer, 2007, pp 287-298

32. Scranton P: Large firms and industrial restructuring: the Philadelphia Region, 1900-1980. Pa Mag Hist Biogr 116:419465,1992

33. Shuttleworth CB: The repair of bony defects of the cranium. Can Med Assoc J 11:562-565, 1921

34. Smith AH: The Life of Russell H. Conwell: Preacher, Lecturer, Philanthropist; with an Appendix Containing Mr. Conwell's Lecture "Acres of Diamonds" and His Oration “Let There be Light." New York: Silver Burdett, 1899

35. The Samaritan Hospital News. Temple Magazine IV:12, 1896

36. The Samaritan Hospital News. Temple Magazine IV:16, 1892

37. The Samaritan Hospital News. Temple Magazine IV:20, 1892

38. Westermann CW: Zur Methodik der Deckung von Schädeldefekten. Zentralbl Chir 43:113, 1916

Manuscript submitted December 15, 2013.

Accepted February 11, 2014.

Please include this information when citing this paper: DOI: 10.3171/2014.2.FOCUS13573.

Address correspondence to: Adam L. Sandler, M.D., Albert Einstein College of Medicine of Yeshiva University/Montefiore Medical Center, Neurological Surgery, 3316 Rochambeau Ave., Bronx, NY 10467. email: adamlsandler@gmail.com. 